\title{
Substantiation of Efficiency of Local Areas of Placement of Production and Processing of Agricultural Products in the Region
}

\author{
Kundius Valentina \\ Department Economic at Altai State Agrarian University \\ Barnaul, Russia \\ kundiusv@mail.ru
}

\author{
Kovaleva Irina \\ Department of Management at Altai State Agrarian \\ University \\ Barnaul, RF \\ irakovaleva20051@rambler.ru
}

\begin{abstract}
Stimulating the development of local territories is the possibility of forming their effective system, which, in turn, implies the emergence of organizations in target market segments with steady demand. The article assesses the distribution of raw material zones of agricultural production and processing enterprises of the Altai Territory region. Criteria are proposed for the segmentation of production and processing of agricultural products, local markets, assessing the effectiveness of localization of production and markets. An integrated approach to assessing the suitability of territories for organic farming is proposed. The cluster going is in this connection expedient near organization of production and processing of organic agricultural produce with the purpose of working off forms and mechanisms of his development.
\end{abstract}

Keywords: segmentation production, criteria, localization efficiency, organic agriculture, clusters

\section{INTRODUCTION}

The Improving the quality of life of the population of almost all countries of the world causes consumption and demand of high-quality, organic and environmentally friendly food products, respectively, the development of organic agriculture and organic processing. At the same time, first of all, basic conditions are required - clean air, water and soil resources, measures to preserve them and prevent the possibility of depletion, respectively, certification of soils, water resources, and assessment of airspace.

The organization of the production and processing of organic agricultural products requires the development or adaptation of eco- biotechnology, the formation of a market for environmental services, including in the laboratory studies of the quality of raw materials components suppliers, certification of products, consulting services and others, ecosystem management organizations. Of course, it is impossible to meet these conditions everywhere and at a time,

The research was conducted with the financial support of the RFFI on a grant for the implementation of the scientific project No. 19-510-44011 "Developing the concept of organic agriculture development based on progressive methods and technologies" it is advisable to scientifically substantiate local areas of agricultural production and processing in the region, the formation of environmentally- economic products in them. Cluster. This article reflects the results of scientific research in this direction.

\section{LITERATURE REVIEW AND RESEARCH METHODS}

Based on theoretical and methodological research - the work of domestic and foreign scientists on the development of organic agricultural production; Land development; research and recommendations of the Russian Academy of Agricultural Sciences, laws, presidential decrees and executive orders of the Government of the Russian Federation, regulations of the subjects of the Russian Federation, EU regulations on the development of environmental agriculture, IFOAM standards.

The study uses a systematic approach to ensure the complexity and focus of scientific recommendations, analytical, abstract-logical, calculating-constructive, economic-statistical, economic-mathematical, monographic methods of research. The methodical approach to justifying the placement of organic agricultural products and food production, localizing it using method of mapping. The Based on the acceptance of mapping with allocation locally segments based on certain criteria or features based on the points-rating system.

This allows us to distinguish local segments of industry production and organic farming using signs of geographical and behavioral segmentation. At the same time, the criterion of segmentation by geographical basis may be the natural and economic zoning of the area in question; the criterion of 
segmentation by behavioral basis may be the degree of need of the residents of the area for a particular product. In the end, the allocation of segments is reduced to ranking local zones of production and processing of organic agricultural products and markets, forming in them.

\section{THE RESULTS AND DISCUSSION}

The analysis of information sources and scientific publications on the development of organic agricultural production in different countries has shown that there are many definitions of this direction Activities. The term "organic agriculture" was first used in the monograph "View of the Earth", published in 1940, authored by Lord Northbourne. The closest synonyms for the term are "biological agriculture," "environmental agriculture," "biodynamic agriculture," sustainable agriculture ecological economic clusters.

According to the definition in the Alimentations Code, "organic farming principles are a comprehensive agroproduction management system that avoids the use of chemical fertilizers, plant protection products and genetically modified organisms, minimizing atmospheric, soil and water pollution levels, and improving the health and productivity of interdependent communities of plant, animal and human life."
European scientist - agrarian Frank Eichhorn by organic agriculture understands the system of agricultural production, based on natural means, which include crop rotations, composts, biological methods of combating pests, mechanical treatment to maintain soil fertility with the complete exclusion of synthetic fertilizers and plant protection chemicals, additives and genetically modified components."

Western researchers N. Haj and K. Hattham noted that the term "organic agriculture" in the global sense means not only the process of production of certified organic products, but also the management of agricultural production based on the use of natural resources and processes, as opposed to the introduction of inorganic elements in order to increase agricultural productivity.

Based on the definitions presented, we believe that the essence of organic agriculture can be formulated as "a concept that encompasses all farming systems based on natural resources and resources that take into account natural resources needs of the plant and animal life, the natural environment, whose main purpose is the process of producing environmental (organic) products certified by international and national environmental certificates."

As the basic principles of organic agriculture, IFOAM singles out the following: the principle of health (maintaining

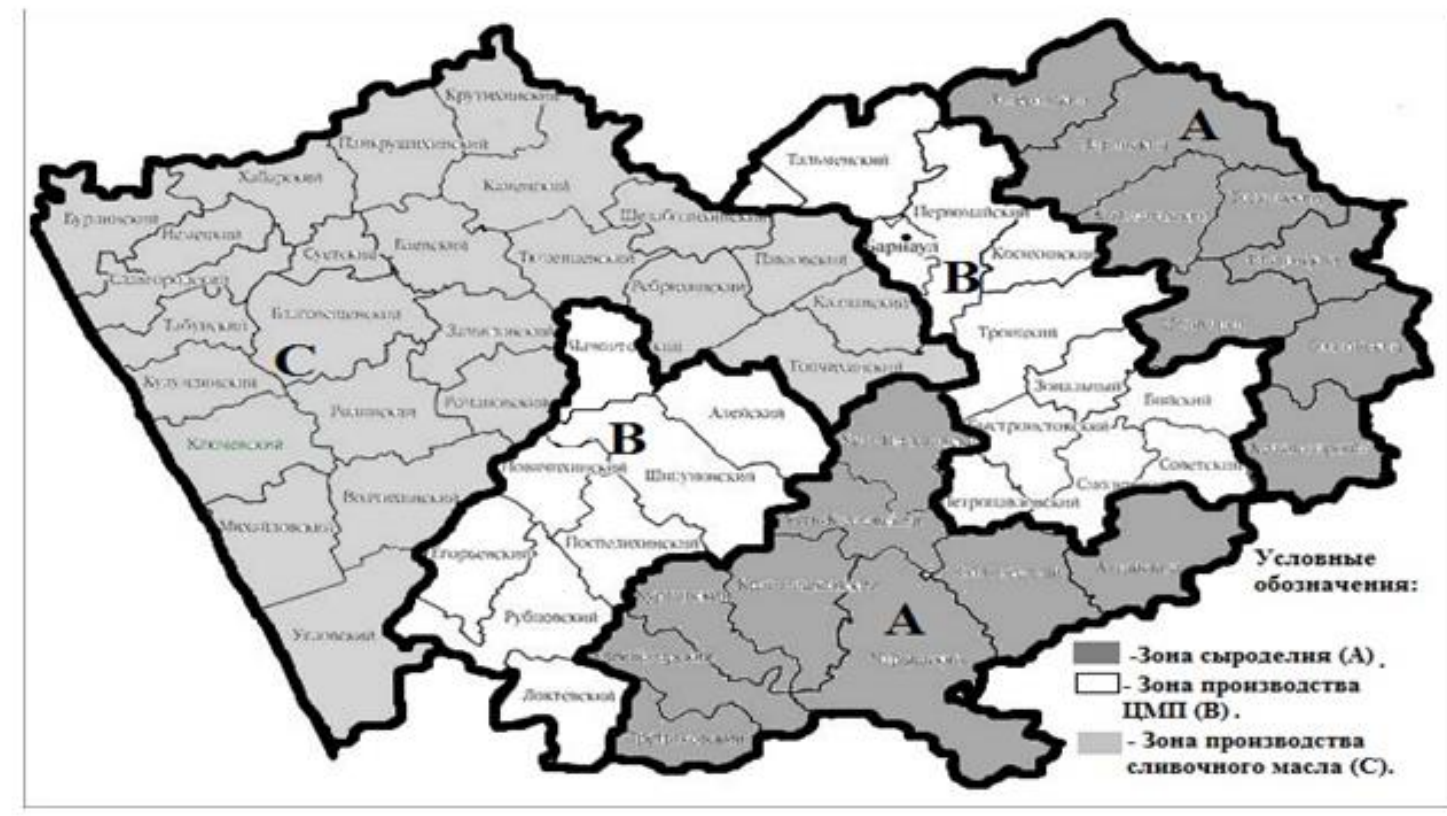

\begin{tabular}{|c|c|c|c|c|c|c|}
\hline \multirow{2}{*}{ Local production } & \multicolumn{2}{|c|}{$\begin{array}{c}\text { Cheese of } \\
\text { different factions }\end{array}$} & \multicolumn{2}{|c|}{ Butter } & \multicolumn{2}{c|}{ Whole milk products } \\
\cline { 2 - 7 } & $\%$ & $\begin{array}{c}\text { Thd. } \\
\text { Tons }\end{array}$ & $\%$ & $\begin{array}{c}\text { Thd. } \\
\text { Tons }\end{array}$ & $\%$ & Thd. Tons \\
\hline Area A & 85 & 66,7 & 15 & 29,3 & 3 & 12,6 \\
\hline Area B & 10 & 7,6 & 20 & 39,0 & 32 & 130,8 \\
\hline Area C & 5 & 4,3 & 65 & 126,8 & 60 & 245,2 \\
\hline
\end{tabular}

Fig. 1. Prospective mapping-zoning of industry-based local dairy production $[8,9,10]$ 
agricultural production can be solved by technology, which is to determine the territorial location of raw materials and processing capacity, with the development of priority strategic specialized segments (areas) for the production and commercial activities of organizations in line with the resource capabilities of territorial agricultural zones. On Fig. 1 presented a project mapping the production of dairy products in the Altai region, ranked by geography and market.

The use of the mapping method allows optimizing not only the local segment in terms of the placement of agricultural raw materials, but also solves issues of socio-economic nature.

The development of the organic market in the Altai region and other regions involves a comprehensive assessment of the suitability of the territories for various forms of economic activity, including estimates of overall biological productivity, comfort of microclimate for recreation, efficiency of rural, forestry and hunting farms with maps and registries. This information is useful for estimating the value of land, optimal use of land and is part of the tasks solved by landscape planning. (Spatial planning, Environmental plans, Land use planning).

It is also necessary to assess the condition and mapping of specific resources and ecosystem services, including: engineering and environmental assessment of the terrain, assessment of the microclimate, potentially for the

In our view, the optimal zone dainty placement of organic

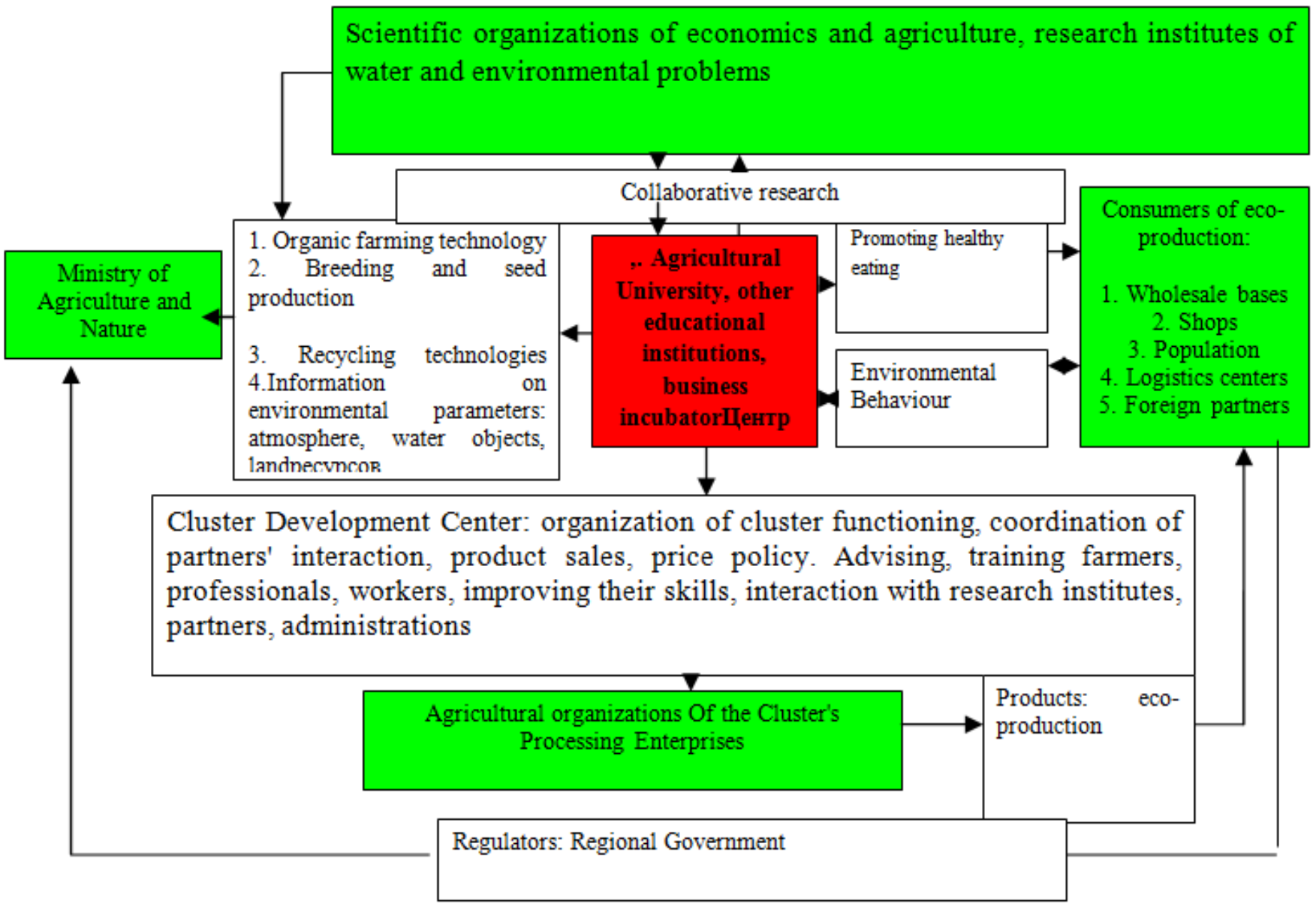

Fig. 2. Organizing - management scheme eco-economic production cluster 
conventionally bare surface and real, with taking into account the spatial structure, vegetation cover, assessment of soil quality and their potential productivity, forest development projects, selection of types and hunting grounds. These issues allow the digital economy to be addressed in terms of estimating the mapping of specific resources, services. The development of organic production is in line with the current trends of the world economy. This is due to the fact that the production of organic products seems to be less harmful to the natural environment of agricultural production. Therefore, and more in comparison with the traditional food market, corresponds to the conditions of sustainable development of the world economy as a whole, adopted by the FAO World Session in Rome in 1996.

Localization of organic production contributes to the organization of eco-economic clusters. Eco - economic production cluster is presented as a complete system of spatially concentrated on the territory of the settlement subjects. Includes public farms and agricultural organizations, peasant (farm) farms, associated local governments, which mutually supplement their functions and interact with the aim of production and implementation environmentally friendly agricultural products, increasing efficiency, enhancing the competitive advantages of its participants, while preserving the environment and resource potential of organic farming. The environmentally-economic production cluster is represented in Fig. 2.

The central component of the organization is the Cluster Development Centre, which operates on a contractual basis. Provides scientific and informational advice on organic farming, eco-production, risks, prices for the necessary means of production and sale of manufactured products, sales channels, provides training to farmers and owners of households in the field of soil science, agro ecology, ecoproduction. The association's use as its main organizational and legal form is fully in line with the principles and objectives of ecosystem management.

The Cluster Development Center carries out the main organizational and managerial functions. The objectives of the Cluster Development Center are: organizing the cluster, coordinating partner interactions, product sales, pricing policy, advising, training farmers, professionals, workers, improving their skills, interaction with research institutes, partners, administrations of the region. Clustering of the economy allows to form a comprehensive view of the state policy of regional development, to increase productivity, efficiency and competitiveness of enterprises, participants of the cluster. Regional governments are coordinating and controlling the law.

There are additional opportunities for innovative development as regional governments streamline relations between the region's various economic factors: the centre, large and small businesses, universities and the public; the region's distinctive features for investors are being shaped and, in general, the level of employment and the quality of life of the population are improving. It is the systemic interaction in integrated entities that induces an additional effect. The subjects, united in the cluster, have opportunities to steadily expand the production of eco-products due to the availability of qualified consultations, the implementation of environmental measures in the surrounding areas, opportunities to obtain loans, attract investment.

Small businesses and households get opportunities to develop. At the same time, the problems of rural employment, rural development, rational and efficient use of their resource potential, conservation of the environment, resource potential of rural areas for management are solved ecological agriculture.

\section{CONCLUSION}

Among the most important measures of development of rural eco-economic clusters should be the creation of an effective mechanism for the functioning of clusters, the provision of environmental services. At the same time, scientific institutions, small businesses providing environmental services such as: assessment of natural resources and the environment (environmental monitoring, development of environmental regulations) are gaining new impetus for development. Developing technologies that promote environmental health; Environmental inventory, environmental rationing, environmental advice, environmental audit; reproduction of the natural environment (reclamation of land, cleaning of contaminated soils, reservoirs, recycling of waste production and life); Repair and maintenance of environmental equipment and technology; Environmental information; Environmental education and the formation of ecological culture; Eco-tourism Environmental examination of facilities (territories, buildings and production facilities, products); environmental risk insurance and others. The demand for environmental services is based on the environmental needs of the population and organizations. This demand is strongly influenced by eco-education and education, environmental cul-de-sacs, and the development of environmental legislation.

\section{REFERENCES}

[1] "Conceptual basis for the formation of the organic sector of agriculture" [Electronic resource]. Available at: https://cyberleninka.ru/article/q/ kontseptualnye-osnovy-formirovaniya-or.

[2] "Organic foods", Org. Health Care, Food. And s.-s. Org. Un., 2 ${ }^{\text {nd }}$, M.: The whole world, 2006, 72 p.

[3] D. Avar, V. V. Taran, E. G. Sokolova, and V. G. Stefanovsky, "Market of organic products in Russia: the modern state and potential of development", Agrarian economics of Russia, 2014, no. 5, pp. 29-37.

[4] S. A. Kharitonov, "Organic agriculture and the production of environmentally friendly products in Russia", APC: economy, management, 2011, no. 8, pp. 88-93.

[5] O. Y. Voronkova and V. A. Kundius, "Organizational and Economic justification for the development of organic (environmental) agriculture in the Altai region", Herald of Altai Science, 2014, no. 2, pp. 124-128.

[6] "International Federation of Environmental Agriculture Movements", IFOAM - Organics International [Electronic resource]. Available at: https://www.ifoam.bio.

[7] V. A. Kundius, O. Yu. Voronkova, I. V. Kovaleva, T. V. Streltsova, D. G. Galkin, and M. V. Petrova, "Socio - economic potential of ecological agriculture and ecological tourism in Altai", Monograph, Barnaul: AZBUKA, 2017, 162 p. 
[14]V. A. Kundius, "Cluster approach to the innovative development of the agro-industrial sector of the region's economy", APC: Regions of Russia, 2012, pp. 8-13.

[15]"The cluster approach is the basis for improving the competitiveness of the regional economy" [Electronic resource]. Available at: http://www.strategplann.ru/stati-po-ekonomike/klasternyj-podhod-osnovapovyshenija-konkurentosposobnosti-regionalnoj-ekonomiki.html.

[16]T. V. Tsihan, "Cluster Theory of Economic Development. Theory and management practice", 2003, no. 5, pp. 74-81.

[17]Electronic resource. Available at: www.slowfood-ulitka.ru.

[18]Electronic resource. Available at: www.slowfood foundfation. com [19]Cowes R. Firm, "Market and Law: Pen. C.", M.: Depo, 1993, 420 p.

[20]V. V. Zakrevsky, and S. M. Repeshov, "Organic production and organic food: history of formation, principles and advantages, the state of markets, legislation", Prevention, And a wedge, Medicine, 2011, no. 1 (38), pp. 26-33.

[21]Electronic resource. Available at: https://www.lid.ch/agronews/detail/news/deutschland-bio-umsaetze-steigenstark. Agriculture, Development Strategy, ISPC, Published by Atlantis Press, 2019, pp. 329-333/ 